\title{
Cirrhotic liver explants: regenerative nodule, dysplasia and hepatocellular carcinoma occurrence
}

\author{
Explantes de figado por cirrose: ocorrência de nódulo regenerativo, displasia e carcinoma hepatocelular
}

Daniel Dutra Romualdo da Silva'; Virginia Hora Rios Leite ${ }^{2}$

\section{key word abstract}

Cirrhotic liver explants

The detection of hepatic nodules by imaging techniques in cirrhotic patients has increased and the Macroregenerative nodule growing consensus that these lesions may be premalignant increases their clinical importance and Dysplasia demands precise diagnostic criteria. The prevalence of macroscopic suspect hepatic nodule (MSHN) in Hepatocellular carcinoma cirrhotic livers was analyzed to identify macroregenerative nodule (MRN), dysplastic nodule and hepatocellular carcinoma (HCC) and to evaluate an association between MSHN and HCC. Hepatic nodules larger than $1 \mathrm{~cm}$ and different from the surrounding nodules of the cirrhosis in color and texture were considered MSHN. Sixty-one cirrhotic liver explants were serially sectioned into 0.5 to $0.7 \mathrm{~cm}$ slices and MSHN and protocol samples were examined histologically. Ninety-four MSHN were identified in 26 livers (histologically 11 were cirrhotic nodules, 61 MRN, 12 dysplastic nodules, and ten HCC). HCC was identified macroscopically in one liver and by light microscopy within MSHN in six other livers. The relation between $\mathrm{HCC}$ and MSHN, specifically MRN, was statistically significant. These findings suggest an association between MRN and MSHN with HCC in cirrhotic livers and reinforce the practical importance of histological classification of hepatic nodules in cirrhosis in order to guide the management of patients who are waiting for liver transplant or surgical treatment.
\end{abstract}

A detecção de nódulos hepáticos por técnicas de imagem em pacientes com cirrose tem aumentado, e o consenso de que essas lesões podem ser pré-malignas aumenta sua importância clínica e demanda critério diagnóstico preciso. A prevalência de nódulos hepáticos macroscopicamente suspeitos (NHMS) em fígados com cirrose foi analisada para identificar macronódulo regenerativo (MNR), nódulo displásico e carcinoma hepatocelular (CHC) e para avaliar a associação de NHMS e CHC. Nódulos hepáticos maiores que $1 \mathrm{~cm}$ com cor e textura diferentes dos demais nódulos da cirrose em cada peça foram definidos como NHMS. Sessenta e um fígados explantados por cirrose foram seccionados em fatias de 0,5 a 0,7cm e NHMS e amostras de áreas aleatórias do fígado foram examinadas histologicamente. Noventa e quatro NHMS foram identificados em 26 fígados (à histologia 11 foram nódulos típicos da cirrose; 61, MNR; 12, nódulos displásicos; e dez, CHC). O CHC foi identificado macroscopicamente em um fígado e pela microscopia óptica em NHMS em seis outros. A relação entre CHC e NHMS, especificamente MNR, foi estatisticamente significante. Esses achados sugerem associação entre MNR e NHMS com o CHC em fígados com cirrose e reforçam a importância prática da classificação histológica dos nódulos na cirrose, com o propósito de orientar a conduta médica no manuseio de pacientes que estão à espera de transplante hepático ou de tratamento cirúrgico.

1. MD, sponsored by Programa de Aprimoramento Discente of Pró-Reitoria de Graduação (PAD-PROGRAD) of Universidade Federal de Minas Cerais (UFMG). 2. MD, PhD.

Work developed at the Department of Pathologic Anatomy, Faculdade de Medicina da UFMG. 


\section{Introduction}

The relationship between hepatocellular carcinoma (HCC) and cirrhosis is well established, especially in those secondary to hepatitis $B$ or $C$ virus infection ${ }^{(2,20,23,24,33)}$. The topic of regenerative nodules and dysplasia continues to be a source of much debate and the distinction between nodular lesions in cirrhosis and HCC remains unclear ${ }^{(2)}$.

The analysis of cirrhotic livers reveals macroregenerative nodules (MRN) at a frequency ranging from $14 \%$ to $38 \%(11,15,29,30)$. Some authors have suggested that these nodules can develop HCC, mainly in Asian populations, and consider these lesions to be precancerous. Few studies are available for other populations ${ }^{(9,19,29)}$. The prevalence of liver cell dysplasia in cirrhotic livers and its progression to HCC is still discussed. Prospective studies have suggested that HCC is more common in the presence of dysplasia at a frequency of $24 \%$ to $30 \%(4,5,19,29)$.

Another important question is the nomenclature of the hepatic nodules. In the last few years, the diagnostic criteria and the nomenclature have been extensively reviewed $^{(10,11,15,16,30)}$.

Specialists have also studied the value of radiological imaging techniques in cirrhotic patients for early detection of HCC and differential diagnosis of hepatic nodular lesions ${ }^{(7,13,25,28)}$. However, the screening of high-risk patient populations using serum alpha-fetoprotein and ultrasound is hindered by low sensitivity and specificity ${ }^{(13)}$.

The detection of hepatic nodules by imaging techniques in patients with chronic liver disease has increased and, lately, with the growing consensus that some of these lesions can be premalignant, their clinical importance has increased, with an urgent need for precise diagnostic criteria and a clinically relevant nomenclature ${ }^{(2,15,28)}$.

Hepatic nodular lesions must be studied to identify precancerous lesions in cirrhotic livers and to define the group of patients at high risk for HCC in order to achieve a better prognosis $^{(33)}$. The importance of the histopathologic study of these lesions is to acquire information that will allow an early differential diagnosis of MRN, dysplastic nodules and HCC in liver biopsies.

The objective of the present study was to determine the prevalence of macroscopic hepatic nodular lesions in cirrhotic livers in our service, to identify histologically MRN, dysplastic nodule and HCC, as well as to assess an association between macroscopic suspect hepatic nodules (MSHN) and the HCC.

\section{Material and method}

Sixty-one consecutive and nonselected cirrhotic liver explants from the Liver Transplant Unit of the University Hospital of Universidade Federal de Minas Gerais (UFMG), Brazil, were sent for histopathologic study over a period of 26 months (from January 2000 to March 2002). The specimens were serially sectioned into 0.5 to $0.7 \mathrm{~cm}$ slices and examined by the method of Theise et al..$^{(29)}$ and Hytiroglou et al. ${ }^{(15)}$. The analysis included the detection of cirrhosis characteristics (fibrosis and hepatocytes surrounded by fibrous septa - cirrhotic nodules), MSHN and HCC. Here MSHN were considered to be those larger than $1 \mathrm{~cm}$ and distinctly different from most cirrhotic nodules of the same liver in color and texture as well as bulging above the cut surface ${ }^{(11,15,29)}$. Samples collected for routine histological examination were MSHN (a maximum of ten), protocol samples (four from the right lobe, three from the left lobe and one from the caudate lobe) and HCC. The fragments were fixed in formalin, embedded in paraffin and stained with hematoxylin-eosin, Masson's trichrome, and Gomori's ammoniacal silver.

Microscopic analysis was performed in order to identify hepatocyte regeneration, liver cells dysplasia, low- and highgrade dysplastic nodules, and HCC in MSHN and in protocol samples. The nodules were microscopically classified as: cirrhotic nodule, MRN, dysplastic nodule and HCC based on the International Working Party (IWP) criteria ${ }^{(16)}$. Herein, the histological criteria of MRN included hepatocytes histologically similar to those in adjacent parenchyma in nodules larger than $1 \mathrm{~cm}$ in diameter. Hepatocyte plates and reticulin stroma were normal. Collapse of sinusoids and compression of peripheral cells due to centrifugal growth could be seen. Mitotic activity and atypias were absent ${ }^{(9,16)}$. Cirrhotic nodules were those with the same appearance of MRN, however without centrifugal growth of hepatocytes. Low-grade dysplastic nodules were composed of minimally abnormal hepatocytes with a normal or slightly increased nucleus/cytoplasm ratio and minimal nuclear atypia, and with a possibly eosinophilic cytoplasm. Portal tracts were present and the reticulin framework was normal. Mitotic activity was also absent ${ }^{(16)}$. High-grade dysplastic nodules were those having any of the features of low-grade dysplastic nodule but associated with one or more of the following findings: high nucleus/cytoplasm ratio, nuclear hyperchromasia, irregular nuclear outline, pseudoglandular formation, or cytoplasmic basophilia. Invasion of stroma or portal tracts was absent and the reticulin net was normal(16). $\mathrm{HCC}$ histological criteria included architectural findings such as cell density twice the normal value, trabeculae of three 
or more wide cells without sinusoidal arrangement, clonal cell population, and pseudoglandular structures. Nuclear hyperchromasia, irregular nuclear and cellular contour, prominent nucleoli, and anisonucleosis were present. Portal tracts were absent and reticulin fibers were reduced and disorganized. There were unaccompanied arteries and a moderate number of mitoses. Necrosis and hemorrhage were common findings ${ }^{(10,16)}$.

Clinical information about patients submitted to liver transplant (sex, age and cirrhosis etiology) was collected. The etiologic diagnosis of cirrhosis was determined based on clinical and serological information and morphological findings. However, since we did not have access to patients' data, the time of cirrhosis evolution for each patient was not known.

The collected data were submitted to statistical analysis with the Epi Info software version 6.4 from Centers for Disease Control and Prevention, Atlanta, USA. The mean and standard deviation were analyzed using Student's $t$ test, with the level of significance set at $p<0.05$. The chi-square test or Fisher's exact test was used for comparison of the observed frequencies, with the level of significance set at $p<0.05$.

\section{Results}

The relation between causes of cirrhosis and macroscopic findings in liver explants is shown in Table 1. Ninety-four MSHN were identified in 26 of 61 liver explants (42.62\%) or 3.6 nodules/liver (range: 1 to 10 ). The diameter of the nodules ranged from 1 to $7 \mathrm{~cm}$.
Among $94 \mathrm{MSHN}$, there were 11 (11.7\%) cirrhotic nodules, 61 (64.9\%) MRN, 12 (12.8\%) dysplastic nodules, and ten (10.6\%) HCC (Table 1). The highest frequency of MRN (61/94) in all causes of cirrhosis $(n=61)$ was not statistically significant.

HCC was macroscopically identified in one liver and microscopically in six, as an incidental finding in MSHN, i.e., in $11.4 \%(7 / 61)$ of the sample. Four of the HCC cases were identified in chronic $\mathrm{C}$ virus infection cirrhosis and three in alcoholic cirrhosis, a statistically significant finding $(p<0.034)$. All cases of HCC were observed in livers with MSHN, corresponding to $26.9 \%(7 / 26)$ of them ( $p<$ $0.001)$. In explants with MSHN (26 livers), the association between MRN (61 nodules) and HCC was significant ( $p<$ 0.038; not significant odds ratio). There was no statistically significant association between dysplastic nodules and HCC in the results.

Among the patients, $37.7 \%$ were females and $62.3 \%$ were males. Patient age ranged from 4 to 68 years (42.19 $\pm 18.69)$. The age of patients with MSHN (38.76 \pm 18.4$)$, MRN (35.63 \pm 20.46$),$ HCC (49.57 \pm 4.96$)$, dysplastic nodules (47 \pm 17.59$)$ and cirrhotic nodules $(49 \pm 7.87)$ was not statistically different from that of patients without these lesions. Dysplastic nodules were a more frequent finding in older patients (51.05 \pm 13.48 years; $p<0.005$ ).

\section{Discussion}

The present monitoring for HCC in cirrhotic patients includes serum alpha-fetoprotein level and ultrasound (US) or

Table 1 Etiology of cirrhosis with MSHN and HCC in 61 liver explants. Histological findings in MSHN

\begin{tabular}{|c|c|c|c|c|c|c|c|}
\hline \multirow{2}{*}{ Etiology } & \multirow{2}{*}{$\begin{array}{c}\text { Number of } \\
\text { explants with } \\
\text { MSHN }\end{array}$} & \multirow{2}{*}{$\begin{array}{c}\text { Number of } \\
\text { explants with } \\
\text { HCC }\end{array}$} & \multirow{2}{*}{$\begin{array}{l}\text { Number } \\
\text { of MSHN }\end{array}$} & \multicolumn{4}{|c|}{ Histological findings in MSHN } \\
\hline & & & & $\begin{array}{l}\text { Cirrhotic } \\
\text { nodules }\end{array}$ & MRN & $\begin{array}{l}\text { Dysplastic } \\
\text { nodules }\end{array}$ & HCC \\
\hline Alcoholic $(n=14)$ & 4 & 3 & 19 & 5 & 9 & 2 & 3 \\
\hline Hepatitis C $(n=16)$ & 8 & 4 & 27 & 3 & 15 & 2 & 7 \\
\hline $\begin{array}{l}\text { Auto-immune hepa- } \\
\text { titis }(n=12)\end{array}$ & 8 & 0 & 35 & 0 & 27 & 8 & 0 \\
\hline Cryptogenic $(n=8)$ & 2 & 0 & 4 & 2 & 2 & 0 & 0 \\
\hline $\begin{array}{l}\text { Secondary biliary } \\
\text { cirrhosis }(n=6)\end{array}$ & 2 & 0 & 3 & 0 & 3 & 0 & 0 \\
\hline Others $(n=5)$ & 2 & 0 & 6 & 1 & 5 & 0 & 0 \\
\hline Total $(n=61)$ & 26 & 7 & 94 & 11 & 61 & 12 & 10 \\
\hline
\end{tabular}

MSHN: macroscopic suspect hepatic nodules; HCC: hepatocellular carcinoma; MRN: macroregenerative nodule. 
computed tomography (CT), which, despite being specific, have low sensitivity for the detection of early lesions ${ }^{(7,17)}$. Bennett et al. (3), correlating histopathology with US findings in patients with a cirrhotic liver, showed that sonography has low sensitivity but high specificity in revealing HCC. However, the sensitivity for lesions smaller than $2 \mathrm{~cm}$ was only $13.6 \%$. Ultrasound and CT are not able to differentiate small HCC from dysplastic nodules or MRN ${ }^{(5)}$. Some authors suggest that the ultrasonographic detection of hepatic tumors requires other radiological imaging techniques such as $\mathrm{CT}$ and magnetic resonance imaging (MRI) or even a needle biopsy to differentiate HCC from other nodular lesions, such as dysplastic and regenerative nodules ${ }^{(10,25)}$. A recent study concluded that in patients with liver cirrhosis, MRI is more accurate than spiral computed tomography for the detection of liver nodules and dysplastic nodules. However, tumour size was a restricting factor for these two techniques, which were unable to detect small HCC in more than $60 \%$ of cases $^{(8)}$. Krinski et al. ${ }^{(18)}$ observed that MRI is not sensitive for the diagnosis of nodules smaller than $2 \mathrm{~cm}$. Rickes et al.(27) reported that HCC and regenerative nodules display different vascularization patterns by echo-enhanced powerDoppler sonography and suggest that these characteristics can be useful for their differential diagnosis.

Despite the technological advances in imaging techniques, histopathologic study is the definitive diagnostic method for the differentiation of hepatic nodular lesions. Thus the study of these lesions is important to identify histological parameters that will allow a differential diagnosis and the detection of precancerous lesions in cirrhosis.

The present study detected a prevalence of $42.62 \%$ (26/61) macroscopic nodules (MSHN), a higher value in comparison with other studies: $14.2 \%$ with $n=345^{(11)}, 25 \%$ with $n=44^{(7)}$ and $28 \%$ with $n=155^{(15)}$. In the study of Furuya et al. ${ }^{(11)}$, a larger number of autopsied livers with or without cirrhosis were conducted on. The causes of cirrhosis in our samples were homogeneous and this fact may have led to bias in the results. The average number of MSHN was 3.6 nodules per liver, as compared to averages of 2.9 nodules ${ }^{(15)}$ and four nodules ${ }^{(29)}$ reported in literature. The finding that a large number of MSHN ( $n=94)$ was found to be MRN by histology $(n=61)$ was not statistically significant.

It should be remembered that the method for analysis is essential for the detection of macroscopic nodules (MSHN) in liver explants. According to Theise et al. ${ }^{(29)}, 90 \%$ of these nodules are between 1 and $1.5 \mathrm{~cm}$ in size. As a result, the macroscopic analysis with wide slices can underestimate the data about these lesions.
We found HCC in $11.4 \%$ (7/61) of livers. The frequency of HCC ranged from $8.4 \%$ to $38 \%(15,19,22,29)$ in other studies with a larger number of livers. There was a statistically significant relation between $\mathrm{HCC}$ and MSHN and especially those classified as MRN. However, since the odds ratio was not significant, MRN could not be considered a risk factor for HCC. The association between HCC and MRN was also suggested by Theise et al.(29) and Hytiroglou et al.(15). The precancerous potential of MRN has been discussed in the literature because of the finding of $\mathrm{HCC}$ foci inside MRN-like nodules and because of the prospective data of patients with MRN who developed HCC inside or outside the nodules.

Dysplastic nodules were observed in $12.8 \%$ (12/94) of the MSHN. Other authors have found frequencies of dysplasia ranging from $61 \%$ to $82 \%(15,19,29)$. We believe that the differences can be attributed to the size of the sample, the cause of cirrhosis and time of disease. Another problem is the lack of reproducibility of the histological diagnosis because of the difficulty in achieving a standard nomenclature of dysplastic phenomena ${ }^{(19)}$. Here there was no statistically significant association between dysplastic nodules and HCC as observed in other studies ${ }^{(15,29)}$. Guettier et al. ${ }^{(14)}$ reported that large cell dysplasia was noticed mainly inside MRN or high-grade dysplastic nodules in cirrhotic livers and detected a $40 \%$ prevalence of large cell dysplasia in livers with HCC. Authors ${ }^{(19,32)}$ noticed that small cell dysplasia was the only morphological type of precancerous significance. Le Bail et al. ${ }^{(19)}$ identified a significant association between HCC and dysplasia in cirrhotic liver explants and suggested that dysplasia in needle liver biopsies should be considered a risk factor for HCC. The relative risk of HCC development is higher in cirrhotic patients with dysplasia than in those without dysplasia ${ }^{(5,12)}$. The general consensus is that regenerative nodules or low-grade dysplastic nodules carry low risk or no risk of malignant change, while high-grade dysplastic nodules are considered to carry high risk of malignant change, and some Japanese authors consider these nodules to be early carcinomas ${ }^{(2)}$.

The lack of a relation between dysplasia and HCC in our results can be explained by the sectional design of this study. Thus, since we did not follow the patients in a prospective way and did not know if they had previous dysplasia, we could not detect the sequence of events from dysplasia to HCC. Also, the lack of reproducibility of the histological diagnosis criteria of dysplasia between other studies and ours could be responsible for this fact.

The literature recommends that HCC diagnosis should not be excluded in any dysplastic lesion identified in a ne- 
edle liver biopsy ${ }^{(16)}$. According to Libbrecht et al. ${ }^{(20)}$, large cell dysplasia in a needle liver biopsy of patients with viralinduced chronic liver disease is an independent risk factor for the development of HCC, and can be used to identify a subgroup of patients at high risk for $\mathrm{HCC}$ requiring more intensive screening.

A potential criticism in differentiating precancerous lesions from $\mathrm{HCC}$ in cirrhotic livers is that this differentiation requires a needle biopsy, which may be associated with a risk of needle-tract seeding. In a recent series, the risk of needle-tract implantation was reported to be $1.6 \%$ in 134 patients who underwent tumor biopsies before resection or orthotopic liver transplantation for HCC. This risk needs to be balanced against the information gained regarding a correct diagnosis in order to avoid an unnecessary surgical procedure and to allow clinical follow-up ${ }^{(33)}$. If the patient has severe associated disease, e.g. cirrhosis, surgical treatments can have major consequences and involve the risk of death. A needle biopsy is important as a support procedure for surgical indication ${ }^{(26)}$.

Some features need to be considered to define a regenerative nodule as atypical, aside from overt HCC within the nodule; these conditions suggest directly or indirectly an increased proliferative rate or a clonal expansion in a subpopulation of hepatocytes, both of which are important steps in hepatocarcinogenesis. Some authors suggest immunohistochemical staining for proliferation markers $(15,21)$.
Others have stated that the most reliable way to distinguish dysplastic nodules from regenerative nodules is the application of molecular genetics techniques ${ }^{(16)}$. Tornillo et al. ${ }^{(31)}$ carried out to characterize chromosomal alterations in hepatocellular nodules by comparative genomic hybridization suggested that high-grade dysplastic nodules are closely related to HCC based on the molecular cytogenetic profile, a fact that was not observed in MRN or low-grade dysplastic nodules. The use of cDNA microarray technology to identify novel genes that consistently displayed altered expression levels in the earliest identifiable precursors to HCC, dysplastic and MRN has also been studied ${ }^{(1)}$. Studies that identify reliable markers of $\mathrm{HCC}$ and neoplastic progression will provide a definitive terminology for precancerous hepatic nodular lesions.

On the basis of the present results, we conclude that there is an association of MRN and MSHN with HCC in cirrhotic liver explants and that there is a higher frequency of $\mathrm{HCC}$ in alcoholic and chronic $\mathrm{C}$ virus infection cirrhosis. These data are of practical importance for correct histological identification and classification of the nodular hepatic lesions detected in cirrhosis by imaging techniques, and to guide medical management of patients who are waiting for a liver transplant or surgical treatment, identifying those who are at high risk of HCC development or not. This was a sectional study; case-control and prospective studies are necessary to establish a reliable causal relationship.

\section{References}

I.ANDERS, R.A. et al.cDNA microarray analysis of macroregenerative and dysplastic nodules in end-stage hepatitis $C$ virus-induced cirrhosis. Am J Pathol, v. I 62, n. 3, p. 991-1000, 2003

2. ANTHONY, P. P. Hepatocellular carcinoma: an overview. Histopathology, v. 39, n. 2, p. 109-18, 2001.

3. BENNETT, G. L. et al. Sonographic detection of hepatocellular carcinoma and dysplastic nodules in cirrhosis: correlation of pretransplantation sonography and liver explant pathology in 200 patients. Am J Roentgenol, v. I79, n. I, p. 75-80, 2002.

4. BORZIO, M. et al. Hepatocyte proliferation rate is a powerful parameter for predicting hepatocellular carcinoma development in liver cirrhosis. Mol Pathol, v. 5 I, n. 2, p. 96101, 1998.

5. BORZIO, M. et al. Liver cell dysplasia is a major risk factor for hepatocellular carcinoma in cirrhosis: a prospective study Gastroenterology, v. 108, n. 3, p. 812-7, 1995.

6. BORZIO, M. et al. Ultrasonography-detected macroregenerative nodules in cirrhosis: a prospective study. Gastroenterology, v. II2, n. 5, p. 1617-23, 1997.
7. BURREL, M. et al. MRI angiography is superior to helicoidal CT for detection of HCC prior to liver transplantation: an explant correlation. Hepatology, v. 38, n. 4, p. 1034-42, 2003.

8. DE LEDINGHEN, V. et al. Detection of nodules in liver cirrhosis: spiral computed tomography or magnetic resonance imaging? A prospective study of 88 nodules in 34 patients. Eur J Gastroenterol Hepatol, v. I 4, n. 2, p. 159-65, 2002.

9. FERREL, L. Liver pathology: cirrhosis, hepatitis and primary liver tumors. Update and diagnostic problems. Mod Pathol, v. I 3 , n. 6, p. 679-704, 2000

10. FERREL, L. et al. Proposal for standardized criteria for the diagnosis of benign, borderline and malignant hepatocellular lesions arising in chronic advanced liver disease. Am J Surg Pathol, v. 17, n. I I, p. I I 13-23, 1993.

I I. FURUYA, K. et al. Macroregenerative nodule of the liver: a clinicopathologic study of 345 autopsy cases of chronic liver disease. Cancer, v. 6I, n. I, p. 99-105, 1988.

12. GANNE-CARRIE, N. et al. Predictive score for the development of hepatocellular carcinoma and additional value of liver 
large cell dysplasia in Western patients with cirrhosis. Hepatology, v. 23, n. 5, p. 111 2-8, 1996.

13. GOGEL, B. M. et al. Diagnostic evaluation of hepatocellular carcinoma in a cirrhotic liver. Oncology, v. 14, n. 6, suppl. 3, p. I5-20, 2000.

14. GUETTIER, C. et al. Looking for large-cell dysplasia in liver needle biopsies how and why? Ann Pathol, v. 21, n. 2, p. |37-44, 200|.

15. HYTIROGLOU, P. et al. Macroregenerative nodules in a series of adult cirrhotic liver explants: issues of classification and nomenclature. Hepatology, v. 21, n. 3, p. 703-8, 1995.

16. INTERNATIONAL WORKING PARTY (IWP). Terminology of nodular hepatocellular lesions. Hepatology, v. 22, n. 3, p. 983-93, 1995.

17. KIM, C. K.; LIM, J. H.; LEE, W. J. Detection of hepatocellular carcinomas and dysplastic nodules in cirrhotic liver:accuracy of ultrasonography in transplant patients. J Ultrasound Med, v. 20, n. 2, p. 99-104, 2001.

18. KRINSKY, G. A. et al. Hepatocellular carcinoma and dysplastic nodules in patients with cirrhosis: prospective diagnosis with MR imaging and explantation correlation. Radiology, v. 219 , n. 2, p. 445-54, 2001.

19. LE BAIL, B. et al. Prevalence of liver cell dysplasia and association with $\mathrm{HCC}$ in a series of 100 cirrhotic liver explants. J Hepatol, v. 27, n. 5, p. 835-42, 1997.

20. LIBBRECHT, L. et al. Predictive value of liver cell dysplasia for development of hepatocellular carcinoma in patients with non-cirrhotic and cirrhotic chronic viral hepatitis. Histopathology, v. 39, n. I, p. 66-73, 2001.

2 I. MELLO, E. S. Macronódulos em figados cirróticos: estudo morfológico com ênfase nos aspectos macroscópicos, proliferação e apoptose. São Paulo, 2002.Tese (doutoramento) - Faculdade de Medicina da Universidade de São Paulo.

22. MION, F. et al. Adult cirrhotic liver explants: precancerous lesions and undetected small hepatocellular carcinomas.
Gastroenterology, v. II I, n. 6, p. I587-92, 1996.

23. MOLMENTI, E. P.; KLINTMALM, G. B. Hepatocellular cancer in liver transplantation. J Hepatobiliary Pancreat Surg, v. 8, n. 5, p. 427-34, 200 I.

24. MONTO, A.;WRIGHT,T. L. The epidemiology and prevention of hepatocellular carcinoma. Semin Oncol, v. 28, n. 5, p. 44I 9, 2001.

25. MURAKAMI, T.; MOCHIZUKI, K.; NAKAMURA, H. Imaging evaluation of the cirrhotic liver. Semin Liver Dis, v. 21, n. 2 , p. $213-24,2001$.

26. OHTOMO, K.; ITAI,Y. Imaging of hepatocellular carcinoma. Dig Surg, v. 12, p. 22-33, 1995.

27. RICKES, S. et al. Evaluation of Doppler sonographic criteria for the differentiation of hepatocellular carcinomas and regenerative nodules in patients with liver cirrhosis. Ultraschall Med, v. 23, n. 2, p. 83-90, 2002.

28.TANAMI,Y. et al. Outcome of hepatic nodules less than $10 \mathrm{~mm}$ in size detected by ultrasonography in patients with chronic liver disease. Nippon Igaku Hoshasen Gakkai Zasshi, v. 62, n. I, p. 17-22, 2002

29.THEISE, N. D. et al. Macroregenerative nodules and hepatocellular carcinoma in forty-four sequential adult liver explants with cirrhosis. Hepatology, v. 16, n. 4, p. 949-55, 1992.

30. THEISE, N. D. Macroregenerative (dysplastic) nodules and hepatocarcinogenesis: theoretical and clinical considerations. Semin Liver Dis, v. I5, n. 4, p. 360-7I, 1995.

3।.TORNILLO, L. et al. Chromosomal alterations in hepatocellular nodules by comparative genomic hybridization: high-grade dysplastic nodules represent early stages of hepatocellular carcinoma. Lab Invest, v. 82, n. 5, p. 547-53, 2002.

32. WATANABE, S. et al. Morphologic studies of the liver cell dysplasia. Cancer, v. 5I, n. 12, p. 2197-205, 1983.

33. WAYNE, J. D. et al. Preoperative predictors of survival after resection of small hepatocellular carcinomas. Ann Surg, v. 235, n. 5, p. 722-31, 2002 